\title{
Uncovering Javanese Islamic Asceticism to Prevent Destructive Tourism Patterns in Gunung Kemukus
}

\author{
Yogi Aji Pangestu ${ }^{1 *}$, Debora Alfi Dwidi Teofani, Rabith Jihan Amaruli \\ * Department of History, Faculty of Humanities, Universitas Diponegoro, Semarang, Indonesia.
}

\begin{abstract}
Gunung Kemukus which is located in Sragen, Central Java, Indonesia, is one of the famous tourist destinations for pilgrims. This place is considered sacred and also attracts tourists to come. The uniqueness lies in the existence of the tomb of Pangeran Samudera, who was a figure of a religious propagator of Majapahit descent and a student of Sunan Kalijaga. In addition, pilgrimage is also a form of Javanese Islamic asceticism that has taken root and become part of the culture of the community. As many pilgrims visit, it has an impact on tourism behavior that destroys both the environment and cultural rites. It can be seen through karaoke houses, rented booths for sex, and environmental pollution. Through a narrative review, this article found that the Javanese Islamic ascetic values believed by the people of Gunung Kemukus could be an effort to preserve the environment and rituals in Gunung Kemukus.
\end{abstract}

\section{Introduction}

Javanese Javanese society is the largest community in Indonesia which has various kinds of ritual traditions that are still carried out today as a symbol with meaning and is used for specific purposes [1]. Traditional ceremonies are used as a medium to convey messages from a form of culture that has been carried out before humans knew writing and continues to this day [2]. The evidence that Javanese society still maintains its culture in the modern era is by looking at their behaviour based on philosophical values or what is called Kejawen [3]. Javanese society has long had a mystical belief that has always experienced the development and acculturation of other influences, such as Hinduism, Buddhism, and Islam. One form of Javanese ritual is a pilgrimage, a form of Javanese Islamic asceticism [4]. The tradition of pilgrimage, which is still very strong among the Javanese Muslim community, makes it a separate agenda used to fulfil their religious activities. Pilgrimage activity is a culture that is still highly respected because it has its value for the perpetrators [5]. According to Max Weber, religious actions are part of social actions that exist in society [6]. It can be said that pilgrimage activities, especially grave pilgrimages, are motivated by a theological understanding that comes from the teachings of Sufism about a religious figure or a figure who can give blessings to pilgrims [7].

\footnotetext{
* Corresponding author: yogiajipangestu@students.undip.ac.id
} 
One of the religious tourism destinations or pilgrimage destinations in Java is the tomb of Pangeran Samudera on Gunung Kemukus, Pendem, Sumber Lawang, Sragen, Central Java, Indonesia. Gunung Kemukus is a small hamlet located in the hills on the edge of a reservoir made in Kedungombo [8]. The local community blesses this place as a form of public respect for Pangera Samudera, a descendant of the King of Majapahit and a student of Sultan Demak. He was tasked with spreading Islam in the Java region [9]. The tomb of Pangeran Samudera is unique and has a special attraction for the community because two beliefs develop. The first belief is that a pilgrimage to the tomb of Pangeran Samudera on Gunung Kemukus is made to remember the merits and nobility of the figure of Pangeran Samudera, which also allows people to remember death so that they can draw closer to God. Meanwhile, the second belief that developed in the community and made this place very famous was the ritual of having blessings at the Pangeran Samudera's grave by having sex with the opposite sex who was not husband and wife seven times in one night or for 35 days [10]. This shows that Javanese Islamic asceticism on Gunung Kemukus experiences ambiguity in its practice to achieve worldly pleasures and desires [4]. However, in essence, the pilgrimage to Gunung Kemukus is an expression of Javanese Islamic asceticism [9].

The form of Javanese Islamic asceticism in the pilgrimage, which has become a culture and tradition for the community, can be said to be local wisdom. Siswadi et al. define local wisdom as a piece of knowledge, intelligence, and local community policy. This is also supported by Ardelt's opinion, which states that the existence of local wisdom cannot be separated from its appreciation [11]. Belief in local wisdom is primarily influenced by local perceptions of mystical matters relating to morality and politics, resulting in a pamali belief and so on [12]. This understanding has existed and, until now, persists in the life of the Javanese people, especially those who live on Gunung Kemukus [13].

Wrong interpretation and also the pattern of tourism, which tends to have a lot of negative impacts, should be a particular concern to the community and also the government. The fame of the sacred sex ritual among pilgrims in Gunung Kemukus is left unattended without any serious resolution efforts. Although this increases the welfare of the surrounding community, it seems that it is a small part of the positive influence of this ritual [8]. With this ritual, Gunung Kemukus is better known as the mount of sex [14]. One of the efforts that can be done in tackling destructive tourism patterns is to instil the noble values of Javanese Islamic asceticism, which was initially a pearl of local wisdom that can be used to preserve the environment, both physical and non-physical. Belief in the efficacy of water in Sendang Ontrowulan is part of local wisdom and influences environmental conservation and overcoming damage due to destructive tourist patterns. Then the sacred activity of Pangeran Samudera's grave is also intended as a preventive measure from damage caused by tourists. Therefore, this article will focus on two things. First, what is the value of local wisdom based on Javanese Islamic asceticism in Gunung Kemukus? Second, what and how the tourism patterns have caused damage to both the natural and cultural environment in Gunung Kemukus. Third, how the values of Javanese Islamic asceticism as local wisdom are used to prevent environmental damage (physical and non-physical) in Gunung Kemukus.

\section{Research Method}

This article is a narrative review conducted through four stages: literature collection, verification, analysis, and display. Literature collection is done by searching for secondary literature relevant to the value of Javanese Islamic asceticism in Gunung Kemukus, destructive tourist patterns, and environmental preservation. The keywords used were Gunung Kemukus, Javanese Islamic asceticism, destructive tourism, environmental preservation, and pilgrims. These keywords are combined with conjunctions "and/or". The 
literature collected is as many as 20 journals found in national and international journals accredited in journal portals such as Science Direct, Cambridge Core, JSTOR and Google Scholar. Verification of literature is used both externally and internally by applying the criteria for published journals in 2010-2020 and the substance of the journal literature and proceedings with the value of Javanese Islamic asceticism on Gunung Kemukus destructive tourist patterns and environmental preservation. The data is then analyzed by referring to the process of selecting, simplifying and interpreting interconnected meanings [15]. The results of this process are followed by the data display process, by compiling the writing in a harmonious formula.

\section{Result and Discussion}

\subsection{Javanese Islamic Asceticism}

Asceticism is a religious phenomenon that develops rapidly in religious traditions [16]. Geertz, Stange, Simuh, and Zoetmulder stated that Javanese asceticism was rooted in Javanese Islamic cultural values and was influenced by later religions, especially Islam. The tradition of pilgrimage to the grave to the tomb of Pangeran Samudera is an example of an expression of Javanese Islamic asceticism, which was uprooted from its roots and became dirty because of a deviation from the tradition of blessing [9]. Sumiarni stated that the purpose of the Kejawen ritual was only to focus on worldly pleasures, which was then considered a deviation from the noble teachings of Javanese Islamic mysticism [4].

Until now, pilgrimage activities carried out at the tomb of Gunung Kemukus have always been a phenomenon of Javanese asceticism, which is always interesting to discuss because the ritual activities at Gunung Kemukus are always associated with the activity of looking for pesugihan through the ritual of ngalap berkah with the procession of sex rituals around the tomb of Pangeran Samudra [10]. In carrying out the process of the pilgrimage ritual, several times are applied at Gunung Kemukus, but Jumat Pon and Jumat Kliwon nights are the most frequent visiting times. Pandanwangi said that the peak of the ritual occurred on the first night of Suro (Javanese New Year). The popularity of Gunung Kemukus happened because of the distortion of the myths that had emerged in the area. A mythical deviation occurs in the story about the piety of Pangeran Samudra and the love of his stepmother, Roro Ontrowulan. The two figures are considered mothers and children who commit sexual deviations and love each other. This myth was then developed and continued by today's society [17]. Gunung Kemukus increased in the 1980s since the Sragen Government, through the Tourism Office, providing support to make this place a religious tourism destination.

Several previous studies have not paid particular attention to the aspects of changes in the expression of Javanese Islamic asceticism. Most of the studies that have been carried out tend to be trapped in the descriptive analysis of sexual rituals that occur during pilgrimage activities on Gunung Kemukus. There is still no change in the form of deviations in expressions of Javanese Islamic asceticism. Soepangat, Permadi, and Sumiarni reveal that the practice of Javanese Islamic asceticism in the Gunungain Kemukus, which is coloured by the activities of ngalap berkah, looking for pesugihan, and sexual ritual processions, can be studied from the assumptions about deviations from Javanese Islamic teachings that have developed since hundreds of years ago. The deviation of Javanese Islamic mystical teachings can be related to the opinion expressed by Geertz and Zoetmulder, namely that Javanese mystical concepts are often ambiguous, which can be seen from the aims of Javanese lelaku (Javanese asceticism) in general. Another goal to be achieved is to achieve worldly goals, success or get out of worldly problems. If viewed from a phenomenological point of view, Subagyo and Siswajal mention that the Tomb of Pengran Samudera on Gunung 
Kemukus has objective facts where what is desired and requested by ritual performers, their wishes can be realized and granted such as penglaris, mate, position, and charisma [6]. According to Sutrisno, the tourism industry activities that occur on Gunung Kemukus have a relationship with the exchange system influenced by the capitalist state's political and ideological forces [10]. There has been a commodification of the blessing activity where the expansion of the tourism market and prostitution has led to the ritual activities of the blessing process, which further confirms the deviation of the myth about "sex rituals" as part of the blessing act. Where previously, it was part of the expression of the diversity of Javanese Islamic asceticism. The meaning of tirakat itself is to isolate oneself to a quieter place. This is interpreted by the Javanese community as an inner effort in a certain way to get closer to God so that his wish can be granted [18].

There is a misunderstanding of Tantrayana teachings in Hindu-Buddhism, which we can then relate to the view of open sexual relations in the past Java. Yogi stated that this Tantrayana school is usually associated with a different discipline of asceticism with the practice of conversational asceticism because the Tantras themselves uphold the theory of sublimation in natural asceticism through sexuality [4]. The entry of Islam to Java was marked by cultural and ritual conflicts and internalization of entrenched Hindu, Buddhist and Javanese traditions. Javanese society itself is a religious society full of symbols seen through the behaviour and customs in Javanese society. The existing teachings and moral messages to be conveyed are present in the form of symbols [19]. The public must be aware that the existence of Islam in Indonesia has never been singular due to the spread of Islam, which has led to the emergence of features and variants of Islam that are unique. The entry of Islam to Java was marked by cultural and ritual conflicts and the internalization of entrenched Hindu, Buddha, and Javanese traditions. Islam entered the archipelago when the people had a religion and had their own beliefs, be it animism, dynamism, Hinduism, or Buddhism [20]. Wahyudi stated that the internalization process involving Islam, Buddhism, Hinduism, and Java resulted in unique teaching called Kejawen, which had the essence of asceticism in the concept of manunggaling kawula gusti [4].

The tomb of Pangeran Samudera is attractive compared to other ritual locations in Java because there are two beliefs. First, by making a pilgrimage to the tomb of Pangeran Samudera, there are ritual activities that carry the value of virtue by remembering the merits and nobility of the person being visited. Second, if you want to do a blessing or wish to have your wish granted, you must have an intimate relationship with the opposite sex who is not your husband for 7 (seven) times for 35 days. This second thing made him famous. Pilgrims come from various regions. Their interest and conviction when they came to Gunung Kemukus and performed rituals, they felt that there was an increase in the economy, agricultural business was running smoothly and was in demand in their trading business [17].

\subsection{Destructive Tourism Patterns}

Tourism can be defined as a voluntary and temporary travel activity scheduled to enjoy a tourism object [21]. Meanwhile, according to KBBI, destructive is defined as something destructive, annihilating, or destructive. So, it can be understood that destructive tourism is a form of temporary activity in the form of a visit to an object that has a tourist attraction but is destructive, destroys, or even destroys the object's environment. This also happened on Gunung Kemukus. This statement is evidenced by the consequence of the high number of pilgrims who come for religious tourism or sexual rituals of drinking blessings on Gunung Kemukus, resulting in the emergence of karaoke houses, rented booths for sex, environmental pollution from visitor waste, vehicle fumes, noise pollution, and others that occur as a result of the crowd [13]. This phenomenon should be a concern for every element of society to maintain environmental sustainability on Gunung Kemukus. Efforts to overcome and prevent 
destructive tourism patterns can be carried out by involving aspects of local wisdom. In this case, what is meant by the disclosure of the values contained in Javanese Islamic asceticism as a noble community value that can be used as a preventive effort in overcoming destructive tourism patterns and their relation to environmental preservation? The selection of the use of local wisdom values to mitigate and preserve the environment is based on the potential of Javanese Islamic asceticism as a pearl of local wisdom that the community should live up to in protecting the environment.

The existence and attractiveness of Gunung Kemukus for tourists who want to visit for various purposes and reasons have never decreased from year to year. Of course, this pilgrimage phenomenon on Gunung Kemukus has various impacts on people's lives, including social, cultural, and environmental aspects. The impact of religious tourism activities in the form of burial pilgrimages can be like two opposing blades. One of the impacts discussed in this study is the environmental aspect and its preservation. The increase in the number of tourists visiting Gunung Kemukus is dominated by pilgrims who only want to carry out the sex ritual of raving blessings. This creates a negative stigma for Gunung Kemukus [13].

As a result of the high number of pilgrims who come for religious tourism or sexual rituals of blessing on Gunung Kemukus, it has resulted in the emergence of karaoke houses, rented booths for sex, environmental pollution from visitor waste, vehicle fumes, noise pollution, and so on [13]. This shows a destructive tourism pattern that threatens environmental sustainability. In addition to the physical impact on the environment, the high number of prostitution practices also presents new problems in the community, namely the outbreak of various kinds of venereal diseases that threaten the community, like HIV. However, unfortunately, this is still being ignored because this phenomenon still benefits the community and the government [14].

\subsection{Local Knowledge Based "Environmental" Preservation}

Symbols play an essential role when carrying out daily practices and the implementation of spiritual procession rituals in Javanese culture. I Made Weni revealed that Indonesians think and act because they are motivated by supernatural beliefs and fill the whole world to bring them into balance [22]. The cultural traditions of Gunung Kemukus then became a tourist commodity that began to attract tourists' attention. The local community sees the number of tourists who come to make their life prosperous. A mount is a high place, seen as holy and noble because of its location, which is felt close to God like in the concept of symbolic classification.

Appreciation for a vital object arises because of myths and legends. The continuity of cultural and religious rituals is inseparable from water, just as local people and pilgrims believe the water in sendang has properties. The belief in the efficacy of water in Sendang Ontrowulan is part of local wisdom and has an influence in environmental preservation and overcoming damage due to destructive tourist patterns. Its sacredness is considered tainted by pilgrims' ritual behaviour, which emphasizes the ritual of sexual intercourse [13]. Most of the ritual processions carried out on Gunung Kemukus use water from Sendang Ontrowulan. Even though it has undergone modification and development, the principal value of the ritual and the sacred object of Gunung Kemukus is still believed. The existence of sacralization in local wisdom encourages the process of environmental preservation through respect for the environment. The noble values contained, such as the harmony of humans with the environment, should continue to be passed down to the younger generation born when Gunung Kemukus has become one of the religious tourisms with its "ritual" full of controversy. Rituals that are carried out will always be related to natural aspects, for example, "water" in Sendang Ontrowulan as a condition for "opening" the ritual. 
Shaw et al., Revealed that local knowledge, or can be said as the community, can use local wisdom as an effort in disaster risk management [12]. The people of Gunung Kemukus already have social capital through local wisdom in preserving nature with the Sendang Ontrowulan ritual. Water from sendang is believed to be able to cleanse a person and at the same time as a symbol of physical and spiritual cleansing [13]. The myths present in Sendang Ontrowulan provide an understanding of the perspective of equality between nature and humans who have an equal position and provide another perspective in ecological management. By preserving the trees around Sendang Ontrowulan spring, the community can have accidentally mitigated disasters. Preservation of trees and springs affects the flow of water that comes out, and the opposite will happen if trees are cleared [13]. It is feared that the increasing density of population and pilgrims will affect the quality of spring water. Cooperation is required by the local government, in this case, related agencies, to carry out development. It is also necessary to provide provision regarding environmental preservation, which is given seriously to people who are directly involved in preserving their environment [13].

In addition, environmental preservation can also be done by applying noble values manifested as a symbol of the sacredness of a place so that its sustainability is maintained. The same is the case with the Javanese people, especially those living on the south coast who have long believed in the existence and power of Nyi Roro Kidul and have been going on for generations. So, this has made the people on the south coast protect nature from environmental damage and pollution to avoid catastrophe and disaster that originated from the anger of Nyi Roro Kidul [12]. This can also be applied to conserve the environment and mitigate the impact of environmental damage from the destructive tourism pattern that occurred on Gunung Kemukus. Applying the values of Javanese Islamic asceticism as local wisdom will slowly force and condition the pilgrims to adjust to an environment where they believe that by obeying these values, they will be safe and prosperous until they return to their place [13]. The practice and appreciation of the value of local wisdom for the community is also a form of environmental conservation efforts so that it is not damaged so that its sustainability is maintained. This practice is certainly in line with the mystical understanding and the sacredness of a place. Unwittingly by the community, the exploration of Javanese Islamic ascetic values as local wisdom can be used as an effort to anticipate damage caused by destructive tourist patterns and as an effort to conserve the environment on Gunung Kemukus.

\section{Conclusion}

The increasing number of pilgrims to the tomb of Pangeran Samudera in Gunung Kemukus has negative impacts, namely environmental damage, both ritual and nature, as shown by the emergence of karaoke houses, rented houses for prostitution, and environmental pollution. An effort to prevent this is to apply the values of Javanese Islamic asceticism as local wisdom. This will force the pilgrims to conform because they believe that they will be safe and prosperous by sticking to these values. Such a cultural approach can gradually reduce destructive tourism patterns. Exploration of Javanese Islamic ascetic values as local wisdom can be carried out simultaneously by the government, society, and pilgrims.

This publication is funded by the Department of History, Faculty of Humanities, Diponegoro University, Semarang, Indonesia 2021. The authors would like to thank Noor Naelil Masuroh for her consideration in reading the English version of this article.

\section{References}


1. N. T. Rahayu, S. Setyarto, A. Efendi, Model Pewarisan Nilai-Nilai Budaya Jawa Melalui Pemanfaatan Upacara Ritual, J. Ilmu Komun., 12(1), 55-69 (2014)

2. S. H. Endah, Tradisi Ziarah Di Jawa Tengah, J. Sabda, 6(1), 12-22 (2011)

3. A. Wahyudi, Prosperity Through Sexuality: A Study of Outdoor Sexual Intercourse as a Ritual in Kemukus Gunungain Sragen Central Java, J. Islam. Civiliz., 1(1), 30-39 (2019)

4. M. Soehadha, Komodifikasi Asketisme Islam Jawa: Ekspansi Pasar Pariwisata dan Prostitusi di Balik Tradisi Ziarah di Gunung Kemukus, J. Multikultural \& Multireligius, 12(3), 101-115 (2013)

5. A. Biroli, D. T. Kartono, D. Demartoto, Rasionalitas Wisatawan Wisata Pilgrim (Studi Fenomenologi Terhadap Wisatawan di Kawasan Wisata Pilgrim Desa Gunungpring, Kecamatan Muntilan, Kabupaten Magelang, J. Anal. Sosiol., 4(2), 98-114 (2015)

6. F. J. Nugroho, Ritual Mistis di Dunia Politik: Studi pada Ritual Ngalab Berkah di Gunung Kemukus, Hanifiya J. Studi Agama-Agama, 3(1), 14-26 (2020)

7. S. Syahdan, Ziarah Perspektif Kajian Budaya (Studi pada Situs Makam Mbah Priuk), J. Studi Agama Masyarakat, 13(1), 65-99 (2017)

8. T. Triyanto, Ritual Ngalab Berkah dalam Mencari Kekayaan di Gunung Kemukus, J. Univ. Teuku Umar, 1(1), 84-96 (2015)

9. A. Hidayat, Rekonstruksi Pendidikan Islam dalam Perubahan Mindset, Edukasia J. Penelit. Pendidik. Islam, 13(2), 413-430 (2018)

10. R. Setiawat, K. A. Safitri, Bahasa Pada Komunikasi Ritual Ziarah Ngalap Berkah di Kawasan Wisata Gunung Kemukus Sragen Jawa Tengah, J. Sos. Hum. Terap., 1(1), 21$31(2018)$

11. R. H. Sari, H. Taqwaddin, S. Syamsidik, Kearifan Lokal Smong Masyarakat Simeulue Dalam Kesiapsiagaan Bencana 12 Tahun Pasca Tsunami, J. Ilmu Kebencanaan, 3(1), 27-32 (2016)

12. A. Findiyani, N. J. Utama, K. Anwar, Kearifan Lokal Dan Mitigasi Bencana Masyarakat Pantai Selatan Kabupaten Cilacap, J. Indones. Hist., 9(1), 28-37 (2020)

13. F. J. Nugroho, A. D. Rengganis, Mitigasi Ekologi di Obyek Wisata Religi Gunung Kemukus, Religi J. Studi Agama-Agama, 16(7), 1-17 (2020)

14. R. Setiawati, P. Priyanto, Komunikasi Ritual Peziarah 'Ngalap Berkah' Di Kawasan Wisata Gunung Kemukus (Studi Etnografi Komunikasi Tentang Budaya Ritual Ziarah Di Kawasan Wisata Gunung Kemukus, Desa Pendem, Kecamatan Sumber Lawang, SragenJawa Tengah, J. Vokasi Indones., 3(2), 74-84 (2015)

15. N. Herlina, Metode Sejarah, (Satya Historika Bandung, 2020)

16. S. Hamali, Asketisme Dalam Islam Perspektif Psikologi Agama, Al-Adyan J. Studi Lintas Agama, 10(2), 202-215 (2015)

17. M. R. Purwanto, S. Sularno, Motivasi Ziarah di Makam Pangeran Samudra Gunung Kemukus dan Mitos Ritual Hubungan Seks.

18. I. A. Sari, M. A. Azhar, T. Erviantono, Indah Ambar, Muhammad Ali Azhar, dan Tedi Erviantono. 2016. 'Mitos Dan Kekuasaan (Studi Kasus Hegemoni Ngalap Berkah Gunung Kemukus terhadap Pencarian Kekuasaan)', E-Jurnal Politika (Politika), 1(1), pp. 1-13 (2016)

19. D. Widiani, J. Jiyanto, Reconstruction of The Story of Prince Samudro: in the Middle of the Myth of the Gunung Kemukus Seksual Ritual, Sumber Lawang, Sragen, J. Lekt. Keagamaan, 17(1), 77-98 (2019) 
20. N. Widiana, Akulturasi Islam dan Budaya Lokal dalam Tradisi 'Nyumpet' di Desa Sekuro Kecamatan Mlonggo Kabupaten Jepara, J. Ilmu Dakwah, 35(2), 286-306 (2015)

21. S. Soedarso, M. Nurif, W. Windiani, Potensi dan Kendala Pengembangan Pariwisata Berbasis Kekayaan Alam dengan Pendekatan Marketing Places (Studi Kasus Pengembangan Pariwisata di Kabupaten Bojonegoro, J. Sos. Hum., 7(2), 136-149 (2014)

22. D. Huda, Peran Budaya Masyarakat Islam Jawa terhadap Kerukunan Umat Beragama, Asketik, 1(2), 45-55 (2017) 